\title{
SEED YIELD AND ITS COMPONENTS OF ALFALFA AS INFLUENCED BY SULFUR AND LAST CUTTING DATE
}

\author{
H. K. Khrbeet \\ Prof. \\ R. Z. A. Al-Beiruty
Lecturer
}

Coll. of Agric. Univ. of Baghdad
N. M. Abood

Assist. Prof.

\section{rz_beiruty@yahoo.com}

\section{ABSTRACT}

A field study was conducted at the experimental farm, Coll. of Agric., Abu-Ghraib, Baghdad, Iraq during the period from mid of march 2013 to end of August 2014 to investigate the effect of different levels of sulfur ( $\left(0,1,2\right.$ and 3 ton. ha $\left.^{-1}\right)$ and three dates of last cutting $\left(1,10^{\text {th }}\right.$ and $20^{\text {th }}$,May 2014)_on seed yield and it's components of alfalfa local cultivar, Layout of the experiment was R.C.B.D. arranged in split -plots with three replications. Sulfur levels were used as main plot and the time when last cutting occurs was sub-plot. Results, showed that addition of sulfur at level more than 1 ton.ha ${ }^{-1}$ $\left(2,3\right.$ ton $\left.\mathrm{ha}^{-1}\right)$ resulted in a significant increasment in the No. of seeds per pod, No. of pods per raceme, No. of racemes per stem, No. of stems per $\mathrm{m}^{-2}$ and seed yield kg.ha-1 . While, No. of ovules per floret, \% of ovules abortion and 1000 seed weight were not significantly influenced by sulfur levels. Highest seed yield $\left(579.4 \mathrm{Kg} \mathrm{ha}^{-1}\right)$ was obtained when sulfur added at level 2 ton ha ${ }^{-1}$. Plants, when last cutting occurred on 10th of May produced highest No. of pods per raceme, No. of stems per $\mathrm{m}^{-2}$ and seed yield $\left(530.8 \mathrm{Kg} \mathrm{h}^{-1}\right)$. There were no significant effect of last cutting date on, No. of ovules per floret, No. of seed per pod, \% of abortion and 1000 seed weight. There were high positive correlation between seed yield and each of No. of seeds per pods, No. of pods per raceme and No. racemes per stem $(+\mathbf{+ 0 . 8 8 0}$, +0.918 and +0.920 ) respectively. This result suggests that yield components may be good selection criteria for breeding seed yield of alfalfa cultivars. High seed yield can be obtained from stands received 2 ton $\mathrm{ha}^{-1}$ and last cutting occurred on $10^{\text {th }}$ May.

Key word: Seed set, Pod formation, Ovules abortion

خربيطو آخرون

مجلة العلوم الزراعية العراقية - 47(5): 1353-1346 /2016

حاصل بذور الجت ومكوناته بتأثير الكبريت وموعد اخر حشة

\author{
نهاد محمد عبود

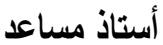 \\ جامعة الانبار - كلية الزراعة- قسم المحاصيل الحقلية
}

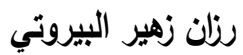
مدرس - - م

حيد خلف خربيط

أستاذ

جامعة بغاد- كلية الزراعة- قسم المحاصيل الحقلية

rz_beiruty@yahoo.com

\begin{abstract}
|لمستخلص
طبقت هذه التجربة في حقل كلية الزراعة / جامعة بغداد - ابو غريب للفترة من منتصف اذار 2013 الى نهاية شهر اب 2014 وذلك لمعرفة تأثثير مستويات مختلفة من الكبريت (0، 1 ، 2 ، 3 طن هـ-1) وثُلاثة مواعيد للحشة الاخيرة قبل اطلاق المحصول للبذور وهي 1، 10، 10، 20 من شـهر مايس 2014 في حاصل البذور ومكوناته الرئيسة للجت (الصنف المحلي). نفنت التجربة بترتيب الالواح المنشقة على وفق تصميم القطاعات الكاملة المعشاة

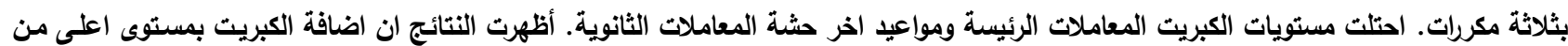
ا طن هـ $1{ }^{-1}$ ، 3 طن هـ -1) قد ادى الى زيادة معنوية في عدد البذور بالقرنة، عدد القرنات بالنورة الزهرية ، عدد النورات الزهريـة بالسـاق الواحد ، عدد

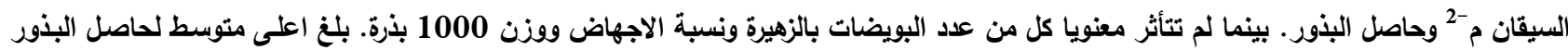
579.45غم هـ -1 عند اضافة 2 طن هـ -1 من الكبريت. اعطت النباتات التي قطعت اخر مرة في العاشر من مايس اعلى متوسط في عدد القرنات بالنورة

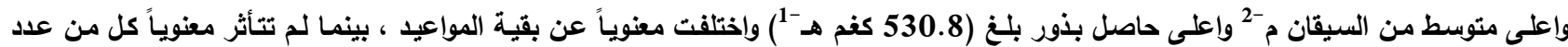
البويضات بالزهيرة وعدد البذور بالقرنة ونسبة الاجهاض ووزن من مأن 1000 بذرة. وجد ارتباط معنوي موجب بين حاصل البذور وكل من عدد البذور بالقرنة ،

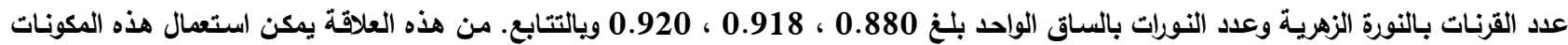

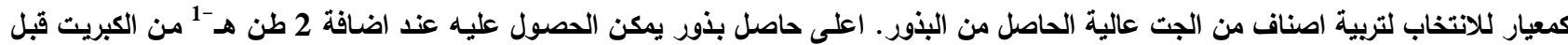
الزراعة واخر حشة للمحصول عند العاشر من مايس.
\end{abstract}




\section{INTRODUCTION}

Alfalfa (Medicago Sativa L.) is a major fodder plant in Iraq and worldwide. But its seed yield is considered to be of secondary important (18), Alfalfa grown for seeds needs different environmental conditions and specific agronomic practices (9).In Iraq, Alfalfa seed crop was generally harvested from field established for forage production, therefore they normally obtaining low seed yield. According to Rincker et al (27) successful alfalfa seed production is favored in regions where the growing season is characterized by low relative humidity and moderate to high temperatures, these environment conditions are similar to that find in Iraq from the period of mid of April to mid of August, unfortunately, the farmer in Iraq, have little knowledge concern the optimum time when this crop should be left for seed setting. Generally they leave the crop to seed set (closing date) after beginning of August or ever later, when the crop is almost exhausted and the conditions become unfavorable for proper seed development, resulting in poor seed yield. Accordingly, seed grower should know about the best time for last cutting of forages in order to bring the seed crop to peak flowering at climatic conditions favor long period of pollinator activity, low incidence of leaf disease and favorable harvest conditions (27).Alfalfa has relatively high demand for sulfur compare to other commonly grown crops (2). Each ton of alfalfa dry matter harvested removes about $27 \mathrm{Kg} \cdot \mathrm{ha}^{-1}$ of $\mathrm{S}$. this quantity removes annually by cutting May reduced the soil content of $S$ and increases the likehood of deficiency. Application of $\mathrm{S}$ with sufficient quantity is therefore become nece ssary especially when these fields preparing for seed production purpose. Most of the work on the effect of $S$ on alfalfa has concentrated on vegetative growth and nodal roots forma tion $(3,11,26)$.Some researcher pointed out that application of $\mathrm{S}$ is more importance in increase seed yield in some forage legumes like white clover (10), Egyptian clover (21) and alfalfa (14). Hilal and Al-Badrawy $(16,17)$ found that applications of sulfur in central Iraq improve soil properties and increase barley seed yield.The objectives of present study was to determine (1) The effect of $\mathrm{S}$ levels on seed yield and seed yield component and (2) the influence of the time of last cutting (Closing date) on subsequent seed yield and it's component.

\section{MATERIALS AND METHODS}

The field experiment was conducted at the Agriculture Experimental Station of the College of Agriculture, University of Baghdad, Abu-Ghraib, during the period from mid- of March 2013 to the end of August 2014. Initial chemical characteristics of the soil (0-30) $\mathrm{cm}$ were shown in Table (1). The previous crop before study establishment was sorghum (Sorghum bicolor L. moench). The grass stand was plowed and was fallow for six month before establishment of alfalfa study.

The experiment was laid out in a (R.C.B.D.) arranged in split plot with three replications four level of sulfur $(0,1,2$ and 3 ton/ ha) referred as S0, S1, S2 and S3 respectively) were added to the soil before planting as main plots the properties of the sulfur used are shown in Table (2) and three closing date for seed set $\left(1^{\text {st }}\right.$ May, $10^{\text {th }}$ May and 20 ${ }^{\text {th }}$ May) were randomly assigned on each of the main treatment as sub-plot. $\mathrm{P}$ and $\mathrm{K}$ were added as recommended $(20,23)$ in the mid of March 2013 seeds of local cultivar were established in $60 \mathrm{~cm}$ drills at seed rate $8 \mathrm{~kg} / \mathrm{ha}(20,22)$. Each sub plot consisted of five rows, each three meter along. Cutting for green forage was conducted when plants reached the $20 \%$ blooming stage. The crop was not left for seed setting during the first year because in the second year the plants reached the best age for seed production $(5,22)$. All experimental plots were hand weeded during summer 2013 and subsequent time. All plots were harvested on end of March 2014 to remove all winter and spring weeds.. The crop was left for seed production on spring 2014 in different close date (1st May, $10^{\text {th }}$ May and $20^{\text {th }}$ May). Foliar application of boron (500ppm), iron (100ppm) and zinc (40ppm) were sprayed at beginning of flowering in each sub plot $(24,1)$ weeds were controlled with hand weeding when necessary. 
Table 1. Some chemical properties of the soil

\begin{tabular}{|c|c|}
\hline E.C. dS.m & -1 \\
pH & 3.5 \\
Nitrogen \% & 7.9 \\
Phosphorus ppm & 0.04 \\
Potassium ppm & 20.2 \\
Sulfur ppm & $\mathbf{8 0 . 2}$ \\
Soil Texture & 2.3 \\
\hline
\end{tabular}

Table 2. Some of properties of Agricultural sulfur used in the experiment ${ }^{*}$.

\begin{tabular}{|c|c|c|c|c|c|c|c|}
\hline $\begin{array}{c}\text { Puri } \\
\text { ty } \\
\% \\
\text { of S }\end{array}$ & $\begin{array}{l}\% \\
\text { of } \\
\text { Imp }\end{array}$ & $\begin{array}{l}\text { Tot } \\
\text { al } \\
\text { uriti } \\
\text { s }\end{array}$ & $\begin{array}{l}\mathrm{HC} \\
\mathrm{O}_{3}^{-}\end{array}$ & $\begin{array}{c}\mathrm{CO} \\
3^{-}\end{array}$ & $\begin{array}{l}\text { C } \\
\mathbf{I}^{-}\end{array}$ & $\underset{++}{\mathbf{M g}}$ & $\begin{array}{c}\text { Ca } \\
++\end{array}$ \\
\hline $\begin{array}{c}99.8 \\
2 \\
\end{array}$ & $\begin{array}{c}0.1 \\
8 \\
\end{array}$ & 180 & 9 & 6 & $\begin{array}{l}1 \\
5\end{array}$ & 90 & 60 \\
\hline$\%$ & $\%$ & \multicolumn{6}{|c|}{ mg per Kg } \\
\hline
\end{tabular}

*Analysis carried out in the central labs. of the Soil and Water Resources Dept. Coll. of Agric. Univ. of Baghdad.

\section{Biological measurement}

At full bloom stage, five racemes were randomly selected from the middle row in each sub plot. Sub sample of two florets were taken from the middle section of the racemes to determine the number of ovules per floret using microscope, the ovary was removed from the calyx and corolla, the ovules dissected out and then counted. Quadrate $\left(0.6 \mathrm{~m}^{-2}\right)$ was taken from the, middle row and harvested when the majority of pods had turned brown (4) to determine the number of stems per quadrate and then converted to $\mathrm{m}^{2}$.

Twenty stem were selected at random and the following seed yield component were determined (1) number of racemes / stem (2) number of pods/ raceme (3) number of seed / pod (4) 1000 seed weight (g). (5) Seed yield was determined from the middle lines, drying were made in the field and threshing was made by hand. (6) \% ovules abortion was determined according to the following equation:-

$$
\begin{aligned}
& \text { Abortion }(\%) \\
& =\frac{\text { Number of ovules }- \text { Number of seeds/pod }}{\text { Number of ovules }}
\end{aligned}
$$

\section{Statistical analysis}

Data were analysis by analysis of variance as described by steel and torrie (30). Means were compared using L.S.D. at the $5 \%$ level of significance. Simple correlation analysis was carried out using SPSS software version 20.

Table 3. Weather condition during April - August 2014 at Abu-Ghraib*

\begin{tabular}{|c|c|c|c|c|c|c|c|}
\hline \multirow{2}{*}{ Months } & \multirow{2}{*}{ Days } & \multicolumn{3}{|c|}{ Temp. $\left({ }^{\circ}\right.$ C) } & \multicolumn{3}{c|}{ Humidity \% } \\
\cline { 2 - 8 } & & Low & High & Avg. & Low & High & Avg. \\
\hline \multirow{4}{*}{ April } & $1-10$ & 16.9 & 30.8 & 24.0 & 20.8 & 64.9 & 39.6 \\
& $11-20$ & 18.0 & 30.6 & 24.0 & 16.1 & 56.0 & 33.8 \\
& $21-30$ & 15.0 & 30.7 & 22.7 & 13.0 & 55.9 & 31.4 \\
& $1-10$ & 20.3 & 30.5 & 25.0 & 34.5 & $\mathbf{8 0 . 0}$ & 57.8 \\
May & $11-20$ & 21.1 & 32.9 & 26.9 & 20.7 & 62.2 & 38.7 \\
& $21-30$ & 22.82 & 37.64 & 30.0 & 13.45 & 57.45 & 31.82 \\
& $1-10$ & 24.6 & 38.2 & 31.2 & 9.7 & 39.5 & 22.7 \\
June & $11-20$ & 24.4 & 39.2 & 31.6 & 11.0 & 42.7 & 25.3 \\
& $21-30$ & 27.1 & 43.9 & 35.3 & 8.3 & 37.9 & 22.0 \\
& $1-10$ & 27.2 & 43.1 & 34.9 & 10.2 & 39.5 & 22.4 \\
July & $11-20$ & 27.4 & 44.1 & 35.8 & 10.9 & 42.6 & 24.8 \\
& $21-30$ & 25.1 & 41.5 & 32.7 & 9.6 & 43.1 & 24.2 \\
\hline
\end{tabular}

*Meteorological data obtained from Al-Raid Results shown in Tables 4 and 5 indicated that station.

\section{RESULTS AND DISCUSSION}

Number of ovules per floret, seed set and \% of ovules abortion

Alfalfa plants produce many more ovules per ovary in each floret, In general there are seven to twelve ovules per floret, but only a few ovules develop successfully into seeds $(19,25)$ application of sulfur and closing dates had significant effect only on number of seeds per pod (seed set) while number of ovules per floret and proportion of ovules abortion were not significantly influenced by application of $\mathrm{S}$, closing dates and their interaction. This result may be due to, that level of $S$ in the soil is enough to invitation and formation of ovules, since competition on nutrients 
probably has accrued in stage when ovules develop into seeds (15). This result was in agreement with Hanon (14) who found, that in pot experiment number of ovules per floret in alfalfa was not significantly influenced by levels of sulfur. In contrast Clifford (10) found, that application of sulfur in white clover support ovules initiation and improving ovules development.Application of $S$ had significant effect on number of seeds per pod Table 4. plants which didn't receive S produced fewer seed per pod (4.46), but it was only significant different than S2 (5.29) and S3 (5.08) which were not significant different to each other. Low seed set in plant received no $S$ was probably due to inadequate supply of $S$ during seed filling. Since Cliffored and White (10) declare, that S play important role in seed filling.Despite, there were no significant effect of $\mathrm{S}$ levels on percentage of ovules abortion, but it seems that application of $S$ resulted in reduction of $\%$ of ovules abortion.Table (5) show, that there were no significant effect of closing dates on mean number of ovules per ovary, seed set and percentage of ovules abortion, This result suggests that the time between $1^{\text {st }}$ May t0 $20^{\text {th }}$ May can initiate and improve ovule development and subsequently in promoting. a good level of seed set.

Table 4. Effect of sulfur levels on mean number of ovules per ovary, seed set and \% of ovules abortion

\begin{tabular}{|c|c|c|c|}
\hline $\begin{array}{c}\text { Sulfur } \\
\text { levels } \\
\text { ton.ha }\end{array}$ & $\begin{array}{c}\text { No. of } \\
\text { ovules per } \\
\text { ovary }\end{array}$ & Seed set & $\begin{array}{c}\text { \% of ovules } \\
\text { abortion }\end{array}$ \\
\hline O (S0) & 7.58 & 4.46 & 40.9 \\
1 (S1) & 7.67 & 4.73 & 36.9 \\
2 (S2) & 7.82 & 5.29 & 31.5 \\
3 (S3) & 7.73 & $\mathbf{5 . 0 8}$ & 34.2 \\
L.S.D. & NS & $\mathbf{0 . 4 1}$ & NS \\
5\% & & & \\
\hline
\end{tabular}

Table 5. Effect of date of last cutting on mean number of ovules per ovary, seed set and $\%$ of ovules abortion

\begin{tabular}{|c|c|c|c|}
\hline $\begin{array}{c}\text { Date of } \\
\text { last } \\
\text { cutting }\end{array}$ & $\begin{array}{c}\text { No. of } \\
\text { ovules per } \\
\text { ovary }\end{array}$ & $\begin{array}{c}\text { Seed } \\
\text { set }\end{array}$ & $\begin{array}{c}\text { \% of } \\
\text { ovules } \\
\text { abortion }\end{array}$ \\
\hline $1^{\text {st }}$ May & 7.56 & 4.81 & 35.9 \\
$\mathbf{1 0}^{\text {th }}$ May & 7.75 & 5.10 & 33.5 \\
$\mathbf{2 0}^{\text {th }}$ May & 7.78 & 4.76 & 38.1 \\
L.S.D. 5\% & NS & NS & NS \\
\hline
\end{tabular}

No. of Stems $/ \mathrm{m}^{2}$

Application of $\mathrm{S}$ had a significant effect on number of stems per $\mathrm{m}^{-2}$. plants which didn't receive $S$ or received low rate of $S$ produced significantly lower number of stems. $\mathrm{m}^{-2}$ than S2 and S3 which were not significantly different to each other (Table 6) the low number of stem in plants received S0 and $\mathrm{S} 1$, probably due to the shortage in reserves in roots and crowns (28). Rehm (26) reported that high level of $S$ increase growth of seedling of alfalfa and encourage crown development. This result was in agreement with Khrbeet (21) working on berseem. Date of last cutting had no significant effect on number of stems. $\mathrm{m}^{-2}$. but it seems that high number of stems can be obtain from plants when last cutting occurred on 10th May (334.8). There were no significant interaction between level of $\mathrm{S}$ and the time when the plants closed for seed set.

Table 6. Effect of sulfur levels and date of last cutting on mean number of stem $\mathbf{~ m}^{-2}$

\begin{tabular}{|c|c|c|c|c|}
\hline \multirow{2}{*}{$\begin{array}{c}\text { Levels } \\
\text { of } \\
\text { sulfur } \\
\mathrm{Kg}_{1} \text { ha }^{-}\end{array}$} & \multicolumn{4}{|c|}{ Date of last cutting } \\
\hline & $\begin{array}{c}\mathbf{1}^{\text {st }} \\
\text { May }\end{array}$ & $\begin{array}{l}10^{\text {th }} \\
\text { May }\end{array}$ & $\begin{array}{l}\mathbf{2 0}^{\text {th }} \\
\text { May }\end{array}$ & mean \\
\hline 0 (S0) & 313.3 & 320.7 & 305.7 & 313.2 \\
\hline 1 (S1) & 298.3 & 310.7 & 312.0 & 307.0 \\
\hline 2 (S2) & 328.7 & 355.7 & 337.7 & 340.7 \\
\hline $3(\mathrm{S3})$ & 340.0 & 352.3 & 358.3 & 350.2 \\
\hline $\begin{array}{c}\text { L.S.D. } \\
\mathbf{5 \%}\end{array}$ & \multirow{3}{*}{320.1} & \multicolumn{2}{|l|}{ NS } & \multirow[t]{3}{*}{20.3} \\
\hline Mean & & 334.8 & 328.4 & \\
\hline $\begin{array}{c}\text { L.S.D. } \\
\mathbf{5 \%}\end{array}$ & & NS & & \\
\hline
\end{tabular}

No. of racemes per stem and No. of pods per raceme

The numbers of ripe racemes' per stem and number of pods per raceme have been identified as the most factors influencing seed yield $(5,29)$. Application of sulfur (S) up to $S 2$ $\left(1\right.$ ton $\left.\mathrm{ha}^{-1}\right)$ significantly increased the number of racemes per stem (Table 7). However, increase the level beyond that limit did not significantly increase this parameter. In the present work the number of racemes appeared over the growing season was higher at S2 (16.77) and S3 (15.67) and lowest at S0 (10.53). This results probably due to the fact that application of $\mathrm{S}$ to the soil may reduce the $\mathrm{pH}$ and then increase phosphorus availability 
$(6,8)$ and nodal roots formation (11). Increase of phosphorus availability could lead to increase cytokinins in the plant and thereby increase number of racemes (13).

Figures of Table 7 showed that plants when last cutting occurred on $1^{\text {st }}$ of May produced significantly low number of racemes per stem (11.82) compared with plants when last cutting occurs on $10^{\text {th }}$ and $20^{\text {th }}$ of May which were not significantly different to each other. This reduces in the number of racemes. Probably due to that the time given to the plant cutting on $1^{\text {st }}$ May is not enough to allow them to build up their food materials to reserve it in the roots or crown, Dovart, et al. (12) found positive correlation between carbohydrate content in roots and crown and the ability of the plant to produce more racemes.

Table 7 Showed that application of sulfur (S) had significant effect on number of pods per raceme, plants which did not receive $\mathrm{S}$ (S0) produced significantly lower number of pods per raceme (7.98) but it was not significantly different than (S1) (8.59) and both were significantly different than S2 (11.63) and S3 (10.47) and the latter significantly different

Table (7) Effect of sulfur levels and date of last cutting on No. of racemes per stem and No. of pods per racemes.

\begin{tabular}{|c|c|c|c|c|c|c|c|c|}
\hline \multicolumn{5}{|c|}{ No. of racemes per stem } & \multirow{2}{*}{\multicolumn{4}{|c|}{\begin{tabular}{|c|} 
No. of pods per raceme \\
Date of last cutting
\end{tabular}}} \\
\hline \multirow[b]{2}{*}{$\begin{array}{l}\text { Levels of sulfur } \\
\text { Ton ha }\end{array}$} & \multicolumn{4}{|c|}{ Date of last cutting } & & & & \\
\hline & $\begin{array}{c}1^{\text {st }} \\
\text { May }\end{array}$ & $\begin{array}{l}\text { 10 }^{\text {th }} \\
\text { May }\end{array}$ & $\begin{array}{l}\mathbf{2 0}^{\text {th }} \\
\text { May }\end{array}$ & mean & $\begin{array}{c}1^{\text {st }} \\
\text { May }\end{array}$ & $\begin{array}{l}10^{\text {th }} \\
\text { May }\end{array}$ & $\begin{array}{l}20^{\text {th }} \\
\text { May }\end{array}$ & mean \\
\hline 0 (S0) & 8.53 & 10.80 & 12.27 & 10.53 & 8.07 & 7.9 & 7.97 & 7.98 \\
\hline 1 (S1) & 9.70 & 13.30 & 14.13 & 12.38 & 7.53 & 9.50 & 8.60 & 8.54 \\
\hline $2(\mathrm{~S} 2)$ & 14.03 & 17.73 & 18.53 & 16.77 & 10.90 & 12.87 & 11.13 & 11.63 \\
\hline 3 (S3) & 15.00 & 15.77 & 16.23 & 15.67 & 9.63 & 11.60 & 10.07 & 10.43 \\
\hline L.S.D.5\% & \multirow{3}{*}{11.82} & \multirow{3}{*}{$\begin{array}{c}\text { N.S. } \\
14.40 \\
1.69\end{array}$} & \multirow{3}{*}{15.29} & \multirow[t]{3}{*}{1.73} & \multirow{3}{*}{9.03} & N.S. & \multirow{3}{*}{9.44} & \multirow[t]{3}{*}{$\mathbf{1 . 0 5}$} \\
\hline Mean & & & & & & 10.47 & & \\
\hline L.S.D.5\% & & & & & & 0.83 & & \\
\hline
\end{tabular}

1000- Seed weight (T.S.W.)

T.S.W. trait was not significantly influenced by sulfur levels, the time of last cutting and their interaction. Despite there were no significant effect on this trait, but it seems that high T.S.W. was obtained from plants received no $\mathrm{S}(2.84 \mathrm{~g})$ which itself produce less number of seed per pod (Table 4). While plants when last cutting occurred on $1^{\text {st }}$ May produce higher T.S.W. (2.84g) which at the same time produce less number of pods per raceme Table 5 , this result may be due to the competion on assimilate during reproductive time phase. than S2. Pod formation is important component of seed yield (31) and it normally a reflection of number of flowers per racemes providing it is successfully pollinated and fertilized. Al- Naimi (7) cited that S had a vital role in plant growth and encouragement of photosynthesis and this in turn could lead to increase carbohydrate availability, possibly explain why plants which received enough quantity of $\mathrm{S}$ had more pods per raceme.

Table 7 showed that plants, which last cutting occurred on $10^{\text {th }}$ May produce significantly highest number of pods per raceme (10.47) compare with plants cutting on $1^{\text {st }}$ May (9.03) and $20^{\text {th }}$ of May (9.44) and both were not significantly different to each other. increase of pods in plants cuts on $10^{\text {th }}$ May possibly due to that, the plants reach flowering on the time favoring nectar secretion and increasing pollinators (Table 3 ) adequate pollinators and attractiveness of the flower are of greater important in ensuring good seed set. Since flowers which were not pollinated may be dried and then fall down.

T.S.W. show significant negative correlation with number of seed per pod (-0.589) and number of pod per raceme (-0.603) Table 9.

Seed Yield: The data of the present study showed that addition of sulfur and the date of last cutting had significant effect on seed yield. But the interaction between those two factors was not significant. plants which did not receive S (S0) produce lower seed yield (446 $\mathrm{kg} \mathrm{ha}^{-1}$ ) but it was not significantly different than $\mathrm{S} 1\left(474.2 \mathrm{~kg} \mathrm{ha}^{-1}\right)$ and both significantly different than S2 (579.4 $\mathrm{kg} \mathrm{ha}^{-1}$ ) and S3 (536.4 $\mathrm{Kg} \mathrm{ha}^{-1}$ ) (Table 8) Application of $\mathrm{S}$ up to 2 ton 
$\mathrm{ha}^{-1}(\mathrm{~S} 2)$ produce significantly high seed yield compare with other levels of (S). addition of $S$ more than 2 ton $\mathrm{ha}^{-1}$ result in a significant reduction in seed yield by $7.5 \%$, Such reduction probably due to reduction in the number of seeds per pod, pods per raceme, and number of racemes per stem which show high positive correlation with seed yield $(0.880 * *$, $0.920^{* *}$ and $\left.0.918^{* *}\right)$ respectively. Increase seed yield after addition of $S$ is probably due to the fact, that added $S$ to the soil may reduce the $\mathrm{pH}$ (6) and then increase availability of phosphorus and some important micronutrients (8) which could lead to increase cytokinns in the plant and thereby increase flowering (13). Higher seed yield was obtained from plants when last cutting was occurred on $10^{\text {th }}$ of May $\left(530.8 \mathrm{~kg} \mathrm{ha}^{-1}\right)$, but it was only significant different compare with plants when last cutting on $1^{\text {st }}$ May (481.1 $\mathrm{kg} \mathrm{ha}^{-1}$ ) (Table 8). Delay the cutting after 10th May reduce seed yield, but such reduction was not significant increase of seed yield on plants when last cutting on $10^{\text {th }}$ May, probably due to increase number of seeds per pod, number of pods per raceme, number of stem per unit area and less \% of ovule abortion all these traits show positive correlation with seed except $\%$ of ovules abortion $\left(0.880^{* *}, 0.830^{* *}, 0.920^{* *}, \quad-\right.$ $0.760 * *$ ) respectively (Table 9).Number of seed per pod, number of pods per raceme and number of racemes per stem show high positive correlation with seed yield indicates that those yield components in combination are the most reliable components for selecting high seed yielding in alfalfa.

Table 8. Effect of sulfur levels and the time of last cutting and their interaction on seed yield $\mathrm{Kg} \mathrm{ha}^{-1}$.

\begin{tabular}{|c|c|c|c|c|}
\hline \multirow{2}{*}{$\begin{array}{c}\text { Levels of } \\
\text { sulfur Ton ha }\end{array}$} & \multicolumn{4}{|c|}{ Date of last cutting } \\
\hline & $\mathbf{1}^{\text {st }}$ May & $10^{\text {th }}$ May & $20^{\text {th }}$ May & mean \\
\hline O (S0) & 415.3 & 481.0 & 441.7 & 446.0 \\
\hline 1 (S1) & 436.3 & 502.0 & 484.3 & 474.2 \\
\hline $2(\mathrm{~S} 2)$ & 559.0 & 598.7 & 580.7 & $579 . .4$ \\
\hline 3 (S3) & 513.7 & 541.3 & 554.3 & 536.4 \\
\hline L.S.D. 5\% & \multirow{3}{*}{481.1} & NS & \multirow{3}{*}{515.2} & \multirow[t]{3}{*}{28.38} \\
\hline Mean & & 530.8 & & \\
\hline L.S.D. 5\% & & 24.68 & & \\
\hline
\end{tabular}

Table 9. Simple correlation coefficients of seed yield component in alfalfa. SEY, Seed yield per unit area; NOO, number of ovules per ovary; NSP, number of seeds per pod; \% OAB, \% of ovules abortion; NST, number of stems per unit area; NRS, number of racemes per stem; NPR, number of pods per raceme; TSW, $100 \mathrm{stem}$; NPR, number of pods per raceme; TSW. 1000 seed weight. *, $\mathbf{P}<0.05 ; * *, \mathbf{P}>0.01$

\begin{tabular}{|c|c|c|c|c|c|c|c|}
\hline Traits & NOO & NSP & $\% \mathrm{OAB}$ & NST & NRS & NPR & TSW \\
\hline SEY & $0.642 * *$ & 0.880 ** & $-0.760 * *$ & $0.830 * *$ & $0.918 * *$ & $0.920 * *$ & $-0.669 * *$ \\
\hline NOO & - & $0.523^{*}$ & -0.223 & 0.357 & $0.683^{* * *}$ & 0.405 & -0.390 \\
\hline NSP & & - & $-0.939 * *$ & $0.931 * *$ & $0.771 * *$ & $0.904 * *$ & $-0.589 *$ \\
\hline$\% О$ & & & - & $-0.645^{*}$ & $-0.631 *$ & $-0.869 * *$ & $0.512 *$ \\
\hline NST & & & & - & $0.785 * *$ & $0.833 * *$ & $-0.766^{* *}$ \\
\hline NRS & & & & & - & $0.848 * *$ & $-0.654 *$ \\
\hline NPR & & & & & & - & $-0.603 *$ \\
\hline TSW & & & & & & & - \\
\hline
\end{tabular}

\section{REFERENCES}

1.Ali, H.S. 2006. Effect of Foliar Application of Zinc and Iron on Seed Yield and Compon ents of Alfalfa and Berseem. Ph.D Dissertation, Dept. of field crops. Coll. of Agric. Univ. of Baghdad pp: 147.

2.Inma, Alfalfa demonstration, alfalfa produ ction guide for Iraq. 2011. info@inmairaq.com
3. Archer, J. 1985. Crop nutrition and fertilizer use printed in Great Britain by page Bros Norwich L.t.d. pp. 258.

4. Askarian, M., J. G. Hamptona and M. J. Hilla. 1995. Effect of row spacing and sowing rate on seed production of Lucerne (Medicago sativa L.) cv. Grasslands Oranga. New Zealand Journal of Agricultural Research 38:289-295. 
5. Al-Dulaimi, H. K.; N.T. Al-Mohammed, an -d H. A. Al-Roumi. 1987. The effect of plant ing method and seeding rate on seed yield and its components of alfalfa (Medicago sativa L.). Iraqi Journal of Agricultural Sciences "ZANCO". 5(4): 7-13.

6. Al-Karkhi, A.A.H. 2014. Effect of Nitrogen, Sulfur Levels and Number of Cutting on Some of Growth Traits, Yield and Green Forage and Grains of Barley. Ph.D. Dissertation, Dept. of Field Crop, Coll. of Agric., Univ. of Baghdad.PP:173.

7.A1- Naimi S.N. 1984. Principles of Plant Nutrition. Univ. of Mosul. Coll. of Agric. press of Mosul Univ. pp. 775.

8. Al-Zahidi, W. F. H. 2005. Effect of Floamy Sulfur, Poultry Fees and Phosphate Rock on Availability and Absorbtion of $\mathrm{P}$ and Some Nutritions of Yield of Wheat. M.Sc. Thesis, Dept. of soil and water Res. Coll. of Agric., Univ. of Baghdad.

9. Bolanos-Aguilar, E.D., C. Huyghe, J. Ecalle, C. Hacquet and B. Julier. 2002. Effect of cultivar and environment on seed yield in alfalfa. Crop Sci. 42(1):45-50.

10.Clifford, P.T.P. and S.D. White. 1986. A sulfur responses: White clover seed production. New Zealand J. of Exp. Agric. 14:97-99.

11.Collins, M., D.J. Lang and K.A. Kelling. 1986. Effect of phosphorus, potassium and sulfur on alfalfa nitrogen-fixation under field conditions. Agron. J. 78:959-963.

12.Dovrat, A., D. Levanon, and M. Waldman. 1969. Effect of plant spacing on carbohydrate in roots and on components of seed yield in alfalfa. Crop sci. 9:33-34.

13.Gray D, and T.H. Thomas. 1982. Seed Germination and Seedling Emergence as Influ -ence by the Position of Development of the Seed Pod, Chemical Applications to the Parent Plant. In: The Physiology and Biochemistry of Seed Development, Dormancy and Germi nation. Ed. A.A.Khan, Amesterdam, New Yor -k. Oxford, Elsevier, pp: 81-110.

14.Hanon, H.N. 2008. Effect of Some Agricult -ural Practices 0n Seed Yield and It's Comp onents of Alfalfa. Ph.D. Dissertation, Dept. of Field Crops. Coll. of Agric. Univ. of Baghdad pp.: 73.
15.Harvey, H. J. 1970: Patterns of assimilate translocation in white clover. Occasional symp -osium of the British Society. 6:181-186.

16.Hilal, M.A and R. Al-Badrawy. 1980. Use of elemental sulfur in Iraqi Agriculture. 111. Effect of added sulfur on the properties of four soil central Iraq. Agricultural and Water Reso urces Research Center. Tech, Bull. No. 37.

17.Hilal, M.A. and R. Al-Badrawy. 1981. Effect of sulfur on barley yield and it's uptake on nutrients it's relation to phosphorus and micronutrients availability. Agricultural and Water Resources Research Center, Sympo sium of different uses sulfur in Iraq, Baghdad. 18.Iannucci, A.; N. Difonzo and P. Marti niello. 2002. Alfalfa seed yield and quality under different forage management sys -tem and irrigation treatment in a mediter -ranean environment. Field Crops Res.78:65-74.

19.Kailerova, J. 1983. Variabillity in the number of ovules in the ovary and its relation to seed setting in Lucerne. Plant Breeding Abstr. 1985.55(6).

20.Khrbeet. H.K. 2003. Effect of row spacing and potassium fertilization on seed yield and it's components in alfalfa. The Iraqi Jour. of Agric. Sci. 34(6):95-102.

21.Khrbeet, H.K. 2005. Effect of sulfur and cutting frequency on seed yield and yield components of berseem. The Iraqi. Jour, of Agric. Sci. 36(4)83-88.

22.Khrbeet, H.K. and A.A. Al-Shamma. 1987. Effect of cutting frequency and seed rate on seed yield and it's components in alfalfa. J. of Agric. Res. and Water resources. 6(1):1-14.

23.Kherbeet, H.K., M.A.K. Al-Timimi, and A.K. Mseer. 1994. Effect of phosphorus fertilization and cutting frequency on seed yield and yield components of alfalfa, The Iraqi. Jour, of Agric. Sci. 25(2):40-48.

24.Khrbeet, H.K. and A.K. Saleh.2003. Effect of foliar application of boron on seed yield and seed yield components of alfalfa. The Iraqi J. of Agric. Sci. 34(1):61-66.

25. Khrbeet, H.K. and R.Z. Al-Beiruty. 2016. Effect of growth regulators on ovule abortion, seed set and germination of two alfalfa cultivars. Accepted for publication and it will be publish in the Iraqi J. of Agric. Sci. Vol. 47(3). 
26.Rehm, G.W. 1987. Application of phosphors and sulfur on irrigated alfalfa. Agron, J.79:973-979.

27.Rincker, C.M., V.L. Marble, DE. Brown and CA. Johasen. 1988. Seed production practices In: Hanson AA, Barnes DK, Hill RR.Ed. Alfalfa improvement. Agronomy Monogram 29. Madison, WI, ASA.CSSA, and SSSA. PP.985-1012.

28.Siem, E.C.; A.C. Caldwell and G.W. Rehm. 1969. Sulfur response by alfalfa on a sulfur deficient soil. Agron. J. 61:368-371.
29.Sengul, S. 2006. Using path analysis to determine Lucerne (Medicago Sativa L.) seed yield and its component. New Zealand J. of Agric. Res. 49:107-115.

30.Steel, R.G.D. and J.H. Torrie. 1980. Principles and Procedures of Statistics. McGraw-Hill Book Company, New York. U.S.D. pp. 485

31.Wenhua, Du; W. Gang; T. Xinhui and A. Humphries.2008. Lucerne growth and components of seed yield as influenced by plant growth regulators. New Zealand J. of Agric.Res. 51:341-348. 